\title{
METHOD DEVELOPMENT AND VALIDATION FOR ESTIMATION OF IRBESARTAN IN BULK DRUG AND PHARMACEUTCAL DOSAGE
}

\author{
Laxmi Banjare*, Jay Kumar Chandra, Prabhat Patel \\ Department of Pharmaceutical chemistry, Shri Rawatpura Sarkar Institute of Pharmacy, Kumhari, - 490042(C.G.), India \\ *Corresponding Author's Email address: banjare.laxmi2@gmail.com
}

\begin{abstract}
:
Simple, sensitive, accurate, precise and rapid ultraviolet (UV) spectrophotometric method was developed for the estimation of Irebesartan in pure form, its formulations and stability samples. Sample recovery in both the formulations using the above method was in good agreement with their respective labeled claims, thus suggesting the validity of the method and noninterference of formulation excipients in the estimation. Detection wavelength was selected as $263 \mathrm{~nm}$ Linearity in response was observed in the range of $10-100 \mu \mathrm{g} / \mathrm{ml}$ having $\mathrm{R}^{2}=0.999 .\left(\mathrm{R}^{2=}\right.$ not less then .996$)$ The regeration equ. $\mathrm{y}=\mathrm{mx}+\mathrm{c}$ was calculated as $\mathrm{Y}=$ The sandell's sensitivity for the developed method was found to be1.6269. The values were founds to be within the official limit. The percentage purity of three different samples, 12,14 , and $16 \mu \mathrm{g} / \mathrm{ml}$ was found to be $92.44,87.49$, 83.47 respectively. The percentage recovery results revealed that the value is $100 \%$, which indicates that the proposed method is accurate as the results are within the official limits.
\end{abstract}

Keywords: ultraviolet (UV) spectrophotometric method, Irebesrtan, recovery experiment, determination of linearity

\section{INTRODUCTION:}

AVAPRO® (irbesartan) is an angiotensin II receptor (AT1 subtype) antagonist. Irbesartan is a non-peptide compound, chemically described as a 2-butyl-3-[p-(o-1Htetrazol-5ylphenyl)benzyl]-1,3-diazaspiro[4.4]non-1-en-4-one.

Its empirical formula is $\mathrm{C}_{25} \mathrm{H}_{28} \mathrm{~N}_{6} \mathrm{O}$, and the structural formula:

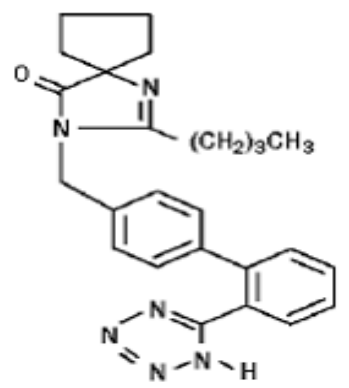

Irbesartan is a white to off-white crystalline powder with a molecular weight of 428.5 . It is a nonpolar compound with a partition coefficient (octanol/water) of 10.1 at $\mathrm{pH}$ of 7.4. Irbesartan is slightly soluble in alcohol and methylene chloride and practically insoluble in water. AVAPRO is available for oral administration in unscored tablets containing $75 \mathrm{mg}, 150 \mathrm{mg}$, or $300 \mathrm{mg}$ of irbesartan. Inactive ingredients include: lactose, microcrystalline cellulose, pregelatinized starch, croscarmellose sodium, poloxamer 188 , silicon dioxide, and magnesium. It has also been tested for use in the treatment of high blood pressure (hypertension) Literature survey reveals that LC, HPTLC, HPLC for determination of content uniformity and simultaneous estimation of Irbesartan is reported, but there is no stability indicating high-performance liquid chromatography (HPLC) method for the determination of Irbesartan from its tablets, as its Pharmaceutical dosage form. The International Conference on Harmonization (ICH) guideline entitled 'Stability Testing of New Drug Substances and Products' requires the stress testing to be carried out to elucidate the inherent stability characteristics of the active substance. Susceptibility to oxidation is one of the required tests(ICH, 1993, 1996). The hydrolytic and the photolytic stability are also required. An ideal stabilityindicating method is one that quantifies the drug per se and also resolves its degradation products. A very viable alternative for stability-indicating analysis of Irbesartan is HPLC. The aim of the present work was to develop an accurate, specific, reproducible, and stability indicating method for the determination of Irbesartan in the presence of its degradation products and related impurities as per ICH guideline. Few analytical methods for the estimation of Irebesartan from plasma2-3, and metabolites including HPTLC4-5, HPLC6-7, and GC8 are reported. To the best of our knowledge, a very few Spectrophotometric methods have been reported. In view of the above fact, some rapid and sensitive analytical methods are in need for its quantitative estimation. The present work describes two simple and accurate spectrophotometric methods for the estimation of Irbesartan in bulk and dosage form stearate.

\section{MATERIALS AND METHODS:}

Drug: The standard sample of Irebesrtan was obtained as gift sample from Dr. Reddy's Laboratory Pvt. Ltd., Hyderabad, A.P., India. The Irebesrtan ablets were procured from local market, manufactured by RANBAXY Laboratories, India.

Instrument specifications: UV Spectrophotometer, Shimadzu, model 1800.

Chemicals and reagents used: Methanol obtained from local market, manufactured by Merck Pharmaceuticals.

Analytical assay - The samples were weighed on electronic analytical balance (Contech Model CB-50)

\section{Preparation of Standard Solutions}

The $10 \mathrm{mg}$ of standard Irbesarten was weighed accurately and transferred into $100 \mathrm{ml}$ volumetric flask. It was dissolved in methanol and diluted up to the mark by using 
the same solvent to obtain a final concentration of $100 \mu \mathrm{g} / \mathrm{ml}$. The resulting solution was used as a working standard solution.

\section{Preparation of Sample Solutions}

For the sample solution each tablet containing $150 \mathrm{mg}$ of Irebesartan 20 tablets were taken and weighed, their mean weight was determined and finely powdered. An equivalent weighed $(10 \mathrm{mg})$ of the tablet content was transferred into a100ml volumetric flask containing $50 \mathrm{ml}$ of ethanol, sonicated for $30 \mathrm{~min}$ and diluted to $100 \mathrm{ml}$ with ethanol. The resulting solution was sonicated for $30 \mathrm{~min}$ and filtered through Whatmann filter paper no.0.45. This solution was used as test solution the methods.

\section{Method for the Determination of detection wavelength}

Standard stock solution of Irebesartan: $150 \mathrm{mg}$ of Irebesartan was accurately weighed and transferred into a clean and dry $100 \mathrm{ml}$ volumetric flask, dissolved with sufficient volume of methanol (AR grade). The volume was then made up to $100 \mathrm{ml}$ with methanol to obtain the concentration of $1000 \mu \mathrm{g} / \mathrm{ml}(1 \mathrm{mg} / \mathrm{ml})$. Working standard solution: $1 \mathrm{ml}$ of the stock solution was further diluted up to $10 \mathrm{ml}$ volumetric flask with methanol to get a concentration $100 \mu \mathrm{g} / \mathrm{ml}$. Serial dilutions of concentration range $2-30 \mu \mathrm{g} / \mathrm{ml}$ were prepared from the working standard solution. These dilutions were scanned in the UV range of 200 to $400 \mathrm{~nm}$ using methanol as blank. The normal mode graphs were converted to first order derivative by software UV probe Shimadzu 2.34. The detection wavelength was thus selected. Is shown in fig no $-1$

Figure 1: Wavelength scanning and determination of absorption maximum

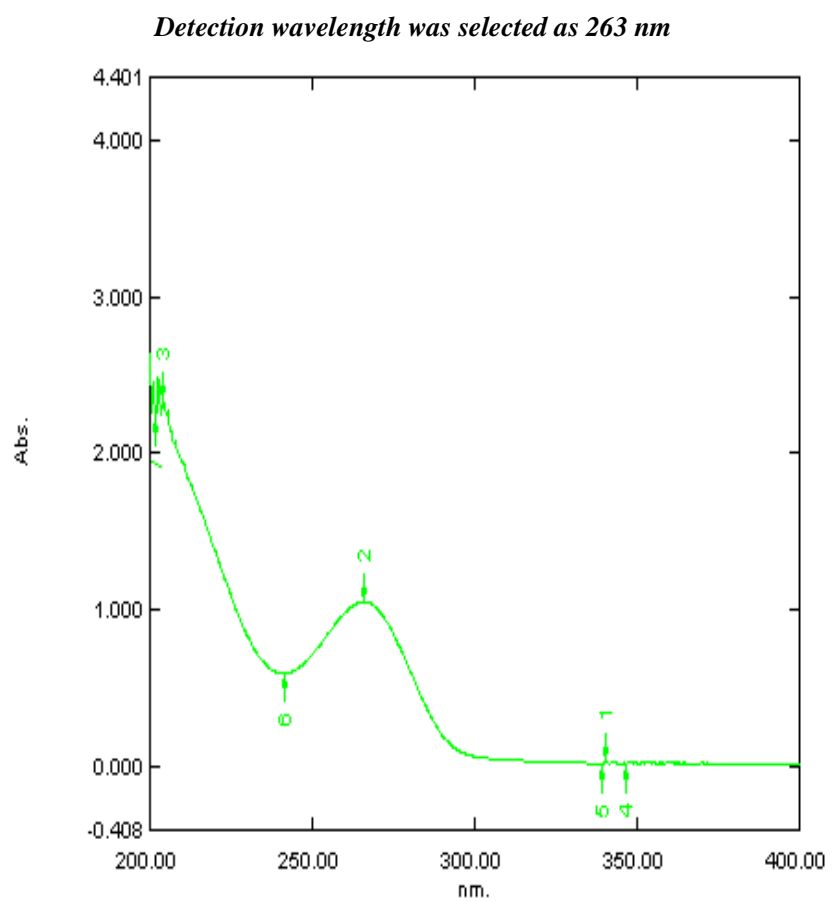

\section{Determination of linearity}

Standard stock solution of Irebesartan: $150 \mathrm{mg}$ of Irebesartan was accurately weighed and transferred into a clean and dry $100 \mathrm{ml}$ volumetric flask, dissolved with sufficient volume of methanol (AR grade). The volume was then made up to $100 \mathrm{ml}$ with methanol to obtain the concentration of $1000 \mu \mathrm{g} / \mathrm{ml}(1 \mathrm{mg} / \mathrm{ml})$. Working standard solution: $1 \mathrm{ml}$ of the stock solution was further diluted up to $10 \mathrm{ml}$ volumetric flask with methanol to get a concentration $100 \mu \mathrm{g} / \mathrm{ml}$. Serial dilutions of concentration range $2-100 \mu \mathrm{g} / \mathrm{ml}$ were prepared from the working standard solution. These dilutions were scanned at the detection wavelength of $263 \mathrm{~nm}$ using methanol as blank. The normal mode graphs were converted to first order derivative by software UV probe Shimadzu 2.34. The regression equation, $\mathrm{Y}$ - intercept and correlation coefficient were calculated. The linearity was thus determined, and a concentration range was selected

Figure 2: Standard Graph Of Irbesartan

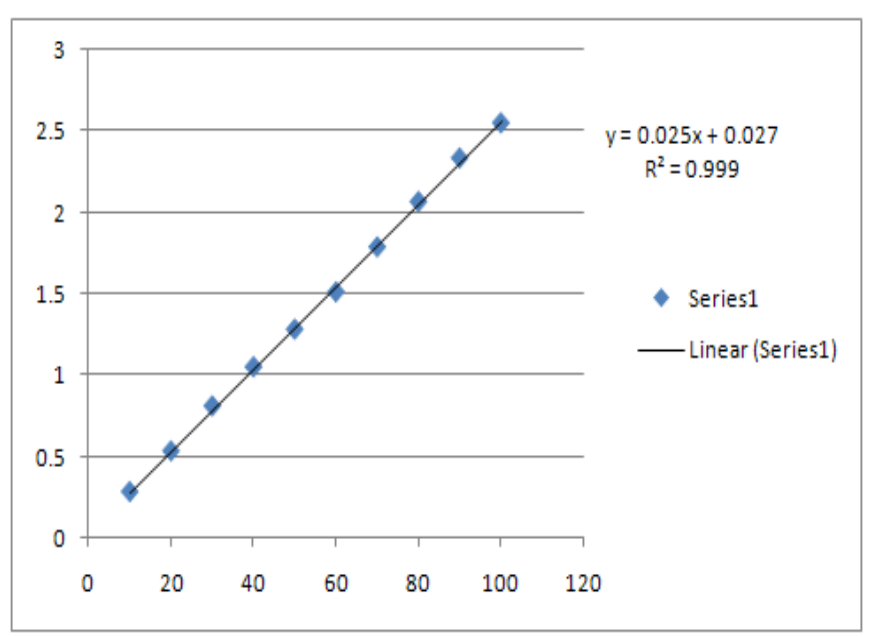

Linearity in the response was obtained in the range of 10$100 \mu \mathrm{g} / \mathrm{ml}$ and regration equation was calculated as $\mathrm{y}=\mathrm{mx}+\mathrm{c}$

$$
\begin{aligned}
& y=0.0253 x+0.0278 \\
& R 2=0.999
\end{aligned}
$$

Figure 3: Derivative graph of the concentration range for Linearity

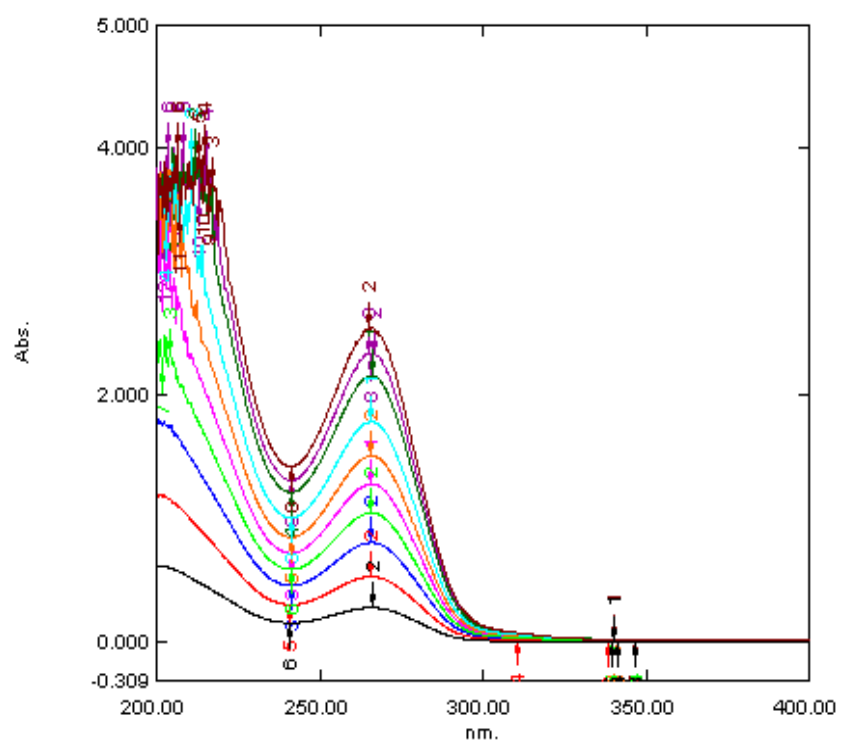

\section{Determination of Sandell's Sensitivity}

Standard stock solution of Irebesartan: $150 \mathrm{mg}$ of Irbesartan was accurately weighed and transferred into a clean and dry $100 \mathrm{ml}$ volumetric flask, dissolved with 
sufficient volume of methanol (AR grade). The volume was then made up to $100 \mathrm{ml}$ with methanol to obtain the concentration of $1000 \mu \mathrm{g} / \mathrm{ml}(1 \mathrm{mg} / \mathrm{ml})$. Working standard solution: $1 \mathrm{ml}$ of the stock solution was further diluted up to $10 \mathrm{ml}$ volumetric flask with methanol to get a concentration $100 \mu \mathrm{g} / \mathrm{ml}$. Serial dilutions of the concentration range $(10-20 \mu \mathrm{g} / \mathrm{ml})$ were prepared from the working standard solution $(100 \mu \mathrm{g} / \mathrm{ml})$. Each of the dilutions was scanned a several times by changing the dilution in the curette during scan at the detection wavelength $263 \mathrm{~nm}$. Convert the obtained normal mode graphs to first order derivative. Note down the observations. From this observation table take the mean of the columns note down the observations in a table and calculate the Sandell's sensitivity from the formula below:

Sandell's Sensitivity (л) = Conc. $(\mu \mathrm{g} / 100 \mathrm{ml})$ x 0.001// $\mathrm{D}_{1}$ value

Table 1: Sandell's Sensitivity

\begin{tabular}{|c|c|c|c|c|}
\hline S .NO. & $\begin{array}{c}\text { CONCENTRATION } \\
(\mu \mathrm{g} / \mathrm{ml})\end{array}$ & ABSORBANCE & SENSITIVITY & $\begin{array}{c}\text { MEAN } \\
\text { SENSITIVITY }\end{array}$ \\
\hline 1 & 10 & 0.4831 & 1.6801 & 1.6269 \\
2 & 20 & 0.6120 & 1.6265 & \\
3 & 30 & 0.7324 & 1.6327 & \\
4 & 40 & 0.8031 & 1.6089 & \\
5 & 50 & 1.2134 & 1.6361 & \\
6 & 60 & 1.3215 & \\
\hline
\end{tabular}

The sandell's sensitivity for the developed method was found to be 1.6269 The values were founds to be within the official limit.

\section{Limit of Detection and Limit of Quantitation}

The LOD and LOQ were separately determined based on calibration curve. The residual standard deviation of a regression line or the standard deviation of $y$ - intercepts of regression lines were used to calculate the LOD and LOQ From the observation table of Sandell's sensitivity, the regression equations, slope an intercept were calculated. The observations were noted down in observation table, the detection limit and quantification limit was calculated by statistical formula.

Table 2: The observations table of LOD and LOQ

\begin{tabular}{|l|l|l|}
\hline SET & SLOPE & INTERCEPT \\
\hline 1 & 0.022 & 0.69 \\
2 & 0.022 & 0.63 \\
3 & 0.022 & 0.68 \\
4 & 0.022 & 0.65 \\
5 & 0.022 & 0.68 \\
6 & 0.022 & 0.68 \\
\hline & MEAN $=0.022$ & SD $=0.000521$ \\
\hline
\end{tabular}

I. Formula for LOD $(\mu \mathrm{g} / \mathrm{ml})$;

$$
\mathrm{LOD}=3.3 \times \mathrm{SD} / \mathrm{S}
$$

Where,

$\mathrm{SD}=$ The standard deviation of the response

$\mathrm{S}=$ The slope of the calibration curve (mean).
II. Formula for LOQ $(\mu \mathrm{g} / \mathrm{ml})$;

$$
\mathrm{LOQ}=10 \times \mathrm{SD} / \mathrm{S}
$$

Where,

$\mathrm{SD}=$ The standard deviation of the response

$\mathrm{S}=$ The slope of the calibration curve (mean).

\section{Accuracy/Recovery Studies}

The stock solution of the formulation was prepared by following method $(1 \mathrm{mg} / \mathrm{ml})$, Weigh powder equivalent to $50 \mathrm{~m}$ of Irebesartan. Dissolve in approximately 30-40 ml of solvent (methanol). Sonicate for 20-30 mins. Make up the volume up to $50 \mathrm{ml}$ with the solvent (methanol). Filter $\&$ use. A stock solution of pure drug sample was prepared $(1 \mathrm{mg} / \mathrm{ml})$.

The three dilutions in the following way:

To the $0.1 \mathrm{ml}$ of the standard stock solution, add $0.05 \mathrm{ml}$ of the test stock (formulation).

To the $0.1 \mathrm{ml}$ of the standard stock solution, add $0.1 \mathrm{ml}$ of the test stock (formulation).

To the $0.1 \mathrm{ml}$ of the standard stock solution, add $0.15 \mathrm{ml}$ of the test stock (formulation).

I. The three dilutions were scanned at detection wavelength $(263 \mathrm{~nm})$, and the $\mathrm{D}^{1}$ values were noted down.

II. Amount of test recovered was calculated by the formula:

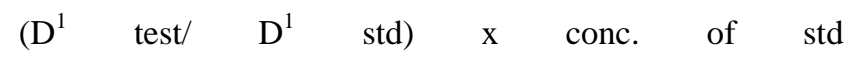

Table 3: Accuracy study

\begin{tabular}{|c|c|c|c|c|c|c|}
\hline S.NO. & TEST $(\boldsymbol{\mu g} / \mathbf{m l})$ & $\begin{array}{c}\text { STANDARD } \\
(\boldsymbol{\mu g} / \mathbf{m l})\end{array}$ & $\begin{array}{c}\mathbf{D}^{1} \text { VALUE AT } \\
\mathbf{2 6 3} \mathbf{~ n m}\end{array}$ & $\begin{array}{c}\text { CONC. } \\
(\boldsymbol{\mu g} / \mathbf{m l})\end{array}$ & $\begin{array}{c}\text { AMOUNT OF TEST } \\
\text { RECOVERED ( } \mathbf{\mu g} / \mathbf{m l})\end{array}$ & $\begin{array}{c}\text { \% } \\
\text { RECOVERY }\end{array}$ \\
\hline 1 & 5 & 10 & 0.015 & 15 & 5 & 100 \\
\hline 2 & 10 & 10 & 0.020 & 20 & 10 & 100 \\
\hline 3 & 15 & 10 & 0.025 & 25 & 15 & 100 \\
\hline
\end{tabular}


The percentage recovery results revealed that the value is $100 \%$, which indicates that the proposed method is accurate as the results are within the official limits. It also reveals that the commonly used excipients and additives in the formulation were not interfering with the proposed method.
Assay

A method to analyze or quantify a substance in a sample. An assay is an analysis done to determine:

1. The presence of a substance and the amount of that substance.

2. The biological or pharmacological potency of a drug.

Table 4: Depicting the assay study

\begin{tabular}{|l|l|l|l|l|}
\hline S.NO. & CONC. $(\boldsymbol{\mu g} / \mathbf{m l})$ & $\mathbf{D}^{\mathbf{1}}$ VALUE AT $\mathbf{2 6 3} \mathbf{~ n m}$ & AMOUNT OBTAINED (mg) & $\begin{array}{l}\text { \% } \\
(\mathbf{w} / \mathbf{w})\end{array}$ \\
\hline 1 & 12 & 0.010 & 6.32 & 92.44 \\
\hline 2 & 14 & 0.014 & 5.26 & 87.49 \\
\hline 3 & 16 & 0.019 & 4.38 & 83.47 \\
\hline
\end{tabular}

The percentage purity of three different samples, 12,14 and $16 \mu \mathrm{g} / \mathrm{ml}$ was found to be $92.44 \%, 87.49 \%$ and $83.47 \%$ respectively.

\section{RESULT AND DISCUSSION:}

Develop some new and sensitive analytical methods for the determination and validation of Irebesartan in bulk and pharmaceutical dosage forms. Detection wavelength was selected as $263 \mathrm{~nm}$ Linearity in response was observed in the range of $10-100 \mu \mathrm{g} / \mathrm{ml}$ having $\mathrm{R}^{2}=0.999$. ( $\mathrm{R}^{2=}$ not less then .996 ) The regeration equ. $y=0.0253 \mathrm{x}+0.0278$ was calculated as $\mathrm{Y}=$ The sandell's sensitivity for the developed method was found to be1.6269. The values were founds to be within the official limit. The percentage purity of three different samples, 12,14 , and $16 \mu \mathrm{g} / \mathrm{ml}$ was found to be $92.44,87.49,83.47$ respectively. The percentage recovery results revealed that the value is
$100 \%$, which indicates that the proposed method is accurate as the results are within the official limits. It also reveals that the commonly used excipients and additives in the formulation were not interfering with the proposed method

\section{CONCLUSION:}

In view of the results, it can be inferred that the UV Spectroscopy may be applied to the determination of Irbesartan as an alternative to the Other UV methods and analytical HPLC methods. Although the precisions of both methods are similar, estimation of Irebesartan is slightly more exact in the derivative approach. Thus, it can be concluded that the Method Developed by the Spectroscopy in the present investigation is simple, sensitive, accurate, rapid and precise. Hence, the above said method can be successfully applied for the estimation of Irebesartan.

\section{REFRENCES:}

1. Bae SK, Kim MJ, Shim EJ, Cho DY, Shon JH, Liu KH, Kim EY, Shin JG. HPLC determination of irbesartan in human plasma: its application to pharmacokinetic studies. Biomed Chromatography, 2009, 23(6), 568-72.

2. Sane R. T., Francis M., Pawar S. Estimation of plasma irbesartan using HPTLC and HPLC. Indian Drug Manufacturers Association, 2003, 40(2). 104-110.

3. ICH, Q2B (1993). Validation of Analytical Procedure: Methodology,International Conference on Harmonization, Geneva, March 1996.

4. ICH, Q1A Stability Testing of New Drug Substances and Products, International Conference on Harmonization, Geneva.

5. Hisharn E and Abdellatef F. Extractive spectrophotometric determination of disopyramide and irbesartan in their pharmaceutical formulation; Spectrochim Acta A. 2007; 66:12481254.
6. Lewis EJ, Hunsicker LG, Clarke WR, Berl T, Pohl MA, Lewis JB, Ritz E, Atkins RC, Rohde R, Raz I. Renoprotective effect of the angiotensinreceptor antagonist irbesartan in patients with nephropathy due to type 2 diabetes. N Engl J Med, 2001, 345(12), 851-60.

7. J.matsoukar and t. mavromostakas. Structure elucidation and conformational properties of Irbesartan. Drug discovery and design, 2002, 174-79.

8. Nevin Erk. Simultaneous determination of irbesartan and hydrochlorothiazide in human plasma by liquid chromatography Journal of Chromatography B, 2003, 784 (1), 195-201.

9. Ashok K. Shakya, Yusuf M. Al-Hiaric and Omran M.O. Alhamami. Liquid chromatographic determination of irbesartan in human plasma. Journal of Chromatography, 2007, 848(2), 245250 . 